\title{
SMR
}

\section{Associations of serotonin receptor gene HTR3A, HTR3B, and HTR3A haplotypes with bipolar disorder in Chinese patients}

\author{
J. Jian ${ }^{1,2 *}$, C. Li ${ }^{1,2 *}$, J. Xu ${ }^{3}$, D. Qiao ${ }^{2}$, G. Mi ${ }^{2}$, X. Chen ${ }^{2}$ and M. Tang ${ }^{2}$ \\ ${ }^{1}$ Shandong University School of Medicine, Ji’nan, Shandong, China \\ ${ }^{2}$ Shandong Mental Health Center Ji'nan, Shandong, China \\ ${ }^{3}$ Business Management Department, \\ Shandong Center for Disease Control and Prevention, Jinan, Shandong, China \\ *These authors contributed equally to this study. \\ Corresponding author: M. Tang \\ E-mail: tangmaoqin12@sina.com \\ Genet. Mol. Res. 15 (3): gmr. 15038671 \\ Received March 30, 2016 \\ Accepted August 8, 2016 \\ Published September 16, 2016 \\ DOI http://dx.doi.org/10.4238/gmr.15038671
}

Copyright (C) 2016 The Authors. This is an open-access article distributed under the terms of the Creative Commons Attribution ShareAlike (CC BY-SA) 4.0 License.

\begin{abstract}
Single nucleotide polymorphisms (SNPs) in HTR3A and HTR3B have been reported to be associated with bipolar disorder in European and Japanese populations. We explored the roles of 21 tag SNPs in HTR3A and HTR3B in susceptibility to bipolar disorder in a Chinese cohort. Twenty-one Tag SNPs were genotyped in a study consisting of 130 patients with bipolar disorder, who visited Shandong Mental Health Center between June 2013 and May 2014, and 109 healthy individuals as controls. All of the tag SNPs were genotyped using Sequenom MassArray matrix-assisted laser desorption/ionization time of flight spectrometry. Plink 1.07, Haploview 4.2, and SPSS 20.0 were used for the analysis of the genotypes and the associations of the haplotypes with bipolar disorder. Association analyses of tag
\end{abstract}


SNPs detected significant associations with the A allele in HTR3A rs1176719 $(\mathrm{P}=0.030)$ and the $\mathrm{C}$ allele in HTR3A rs1176713 $(\mathrm{P}=$ 0.048). Haplotype-based association analyses indicated a statistically significant $(\mathrm{P}=0.035)$ five-SNP haplotype (rs1062613:C, rs11604247:C, rs1176722:G, rs2276302:A, rs1176719:G) of linkage disequilibrium in block 3. Analysis of our small Chinese sample revealed a significant association of HTR3A with bipolar disorder, but yielded no evidence of an association between HTR3B and bipolar disorder. Furthermore, evidence for an association was found for a haplotype of HTR3A. Studies with larger Chinese samples are needed to verify our findings.

Key words: HTR3A; HTR3B; Bipolar disorder; Haplotype; Single nucleotide polymorphism

\section{INTRODUCTION}

Bipolar disorder (BPD) is a severe psychiatric disorder that affects up to $4 \%$ of the adult population worldwide and is characterized by recurrent episodes of depression and mania or hypomania (Fornaro et al., 2016). BPD is classified into bipolar disorder type I and bipolar disorder type II according to the Diagnostic and Statistical Manual of Mental Disorders, 4th edition (DSM-IV) diagnostic criteria (Altinay et al., 2016). Several studies analyzing genetic linkages and candidate genes, and genome-wide association studies (GWAS) have presented evidence of important genetic etiology in BPD (Bauer and Pfennig, 2005; Merikangas et al., 2007).

Serotonin imbalance may be one of the pathogenic mechanisms underlying BPD. Serotonin 3 receptors $(5-\mathrm{HT} 3 \mathrm{~s})$ are unique ligand-gated channel receptors associated with learning, memory, and emotion (Barnes and Sharp, 1999). These receptors are composed of five subunits (Tee et al., 2010): serotonin receptor 3A (HTR3A), serotonin receptor 3B (HTR3B), serotonin receptor 3C (HTR3C), serotonin receptor 3D (HTR3D), and serotonin receptor 3E (HTR3E) (Cederholm et al., 2009). The genes for HTR3A and HTR3B exist in close proximity to each other on chromosome 11q23.2 (Maricq et al., 1991). HTR3A and HTR3B have been cloned in mice for use in an experimental model (Barker et al., 2013). HTR3C, HTR3D, and HTR3E have been established in mammalian experimental models other than rodents (Holbrook et al., 2009; Karnovsky et al., 2003; Niesler et al., 2003). Recent genetic association studies have highlighted the significance of serotonin receptors $3 \mathrm{~A}$ and $3 \mathrm{~B}$ in psychiatric conditions, such as schizophrenia, BPD, alcohol dependence, and depression. 5-HT3 receptors have been shown to be associated with BPD in European and Japanese populations. A Japanese study has revealed that SNPs in HTR3B are associated with depression in female patients based on linkage disequilibrium (LD) (Yamada et al., 2006). Hammer et al. (2012) have confirmed rs1062613, rs1176744, and rs3831455 in the HTR3A and HTR3B genes, and the HTR3B variant rs1176744 as predisposing factors for BPD (Tencomnao et al., 2010; Tee et al., 2010). Niesler et al. (2001)'s findings suggest that c.178C $>$ T (Pro16Ser) is an allele responsible for susceptibility to BPD. Seneviratne et al. (2013) and Johnson et al. (2013) demonstrated that Caucasian or European American subjects carrying one or more specific alleles of the HTR3A and HTR3B genes have significant differences in their responses to ondansetron vs. placebo in terms of drinking (Barker et al., 2013; Tang et al., 2013). Additionally, the interactions of these

Genetics and Molecular Research 15 (3): gmr.15038671 
variants significantly affected alcohol dependency (Weber et al., 2011; Johnson et al., 2013; Seneviratne et al., 2013). However, consistently susceptible gene factors associated with BPD were not found. Significant associations with overlapping haplotypes were not found in other studies.

We attempted to identify a susceptibility gene for BPD using 21 SNPs in HTR3A and HTR3B in Han Chinese patients. HTR3A and HTR3B SNPs were genotyped in order to obtain the haplotypes of the two serotonin receptors to investigate associations with BPD.

\section{MATERIAL AND METHODS}

\section{Subjects}

Samples were collected from 130 patients with BPD, including 68 patients with BPD type I and 62 patients with BPD type II visiting Shandong Mental Health Center in China between June 2013 and May 2014. Samples from 109 healthy individuals who were matched to the patients in terms of age, gender, and years of education were also obtained. Informed consent was obtained from all of the subjects prior to the study. The study was approved by the Ethical Committee board of Shandong University.

Inclusion and exclusion criteria for the patients were as follows: 1) all of the patients were diagnosed with bipolar disorder according to DSM-IV diagnostic criteria and were surveyed using the Structured Interview for DSM-IV. 2) Patients with serious somatic or neurological diseases and other acute or unstable medical conditions were excluded. Those with alcohol abuse and those undergoing addiction counseling were excluded. 3) None of the patients enrolled in the study had a history of alcohol or drug abuse. The healthy subjects enrolled at the same time were volunteers from Ji'nan, Shandong Province. These subjects had no serious somatic or neurological diseases or a history of alcohol or drug abuse.

\section{DNA extraction and PCR amplification}

A total of $5 \mathrm{~mL}$ peripheral fasting heparinized blood were collected from each subject. A QiaAMP Blood Mini Kit (Qiagen, Germany) was used to extract DNA and 200 $\mu \mathrm{L}$ peripheral whole blood sample according to the manufacturer's protocol. A NanoDrop ND-2000 (PEQLab Biotechnologie GmbH, Erlangen, Germany) was used to assess DNA concentration $(10 \mathrm{ng} / \mu \mathrm{L}-20 \mathrm{ng} / \mu \mathrm{L})$ and purity $(260 / 280$ ratio $=1.8-2.0)$ before PCR amplification. Ten nanograms of DNA for the target genes HTR3A and HTR3B (primers designed by AssayDesigner3.1) were amplified.

\section{Selection of tag SNPs and genotyping}

All of the tag SNPs were selected from the National Center for Biotechnology Information (NCBI) dbSNP build 138 (http://www.ncbi. nlm.nih.gov/snp/) and the HapMap Project release for Han Chinese in Beijing, China. The selection criteria for the tag SNPs were $\mathrm{r}^{2}>0.8$ and MAF $>0.1$ (minor allele frequency). The tag SNPs examined in a $100-\mathrm{kb}$ region revealed 10 polymorphisms in HTR3A and 11 polymorphisms in HTR3B (see Table 1). The extended products were genotyped using a Sequenom Mass Array platform for MALDI-TOF spectrometry.

Genetics and Molecular Research 15 (3): gmr.15038671 
Table 1. Tag SNPs and minor allele frequency (MAF).

\begin{tabular}{|c|c|c|c|c|c|}
\hline \multirow{2}{*}{$\begin{array}{l}\text { Gene } \\
\text { HTR3A }\end{array}$} & \multirow{2}{*}{$\begin{array}{c}\text { Tag SNP } \\
\text { rs10789980 }\end{array}$} & \multirow{2}{*}{$\begin{array}{c}\text { Size (bp) } \\
113,970,281\end{array}$} & \multicolumn{2}{|c|}{ Allele } & \multirow{2}{*}{$\begin{array}{c}\text { MAF } \\
0.3734\end{array}$} \\
\hline & & & $\mathrm{G}$ & $\mathrm{A}$ & \\
\hline & rs 1062613 & $113,975,284$ & $\mathrm{~T}$ & $\mathrm{C}$ & 0.1113 \\
\hline & rs11604247 & $113,976,182$ & $\mathrm{~T}$ & $\mathrm{C}$ & 0.1155 \\
\hline & rs1176722 & $113,977,752$ & A & $\mathrm{G}$ & 0.1155 \\
\hline & rs2276302 & $113,979,418$ & $\mathrm{G}$ & $\mathrm{A}$ & 0.1181 \\
\hline & rs1176719 & $113,981,465$ & $\mathrm{~A}$ & G & 0.2458 \\
\hline & rs 10160548 & $113,985,959$ & $\mathrm{G}$ & $\mathrm{T}$ & 0.3347 \\
\hline & rs 1176713 & $113,989,703$ & $\mathrm{C}$ & $\mathrm{T}$ & 0.2353 \\
\hline & rs1182457 & $113,991,027$ & $\mathrm{~T}$ & $\mathrm{C}$ & 0.1151 \\
\hline & rs897685 & $113,993,387$ & $\mathrm{G}$ & A & 0.1029 \\
\hline \multirow[t]{11}{*}{ HTR3B } & rs 10789970 & $113,903,224$ & $\mathrm{C}$ & $\mathrm{T}$ & 0.4097 \\
\hline & rs 3758987 & $113,904,553$ & $\mathrm{G}$ & $\mathrm{A}$ & 0.1757 \\
\hline & rs 3831455 & $113,904,828$ & $\mathrm{G}$ & $\mathrm{T}$ & 0.1610 \\
\hline & rs4938056 & $113,915,817$ & $\mathrm{C}$ & $\mathrm{T}$ & 0.4208 \\
\hline & $\mathrm{rs} 12421126$ & $113,916,487$ & $\mathrm{C}$ & $\mathrm{T}$ & 0.2302 \\
\hline & rs 1176746 & $113,931,879$ & $\mathrm{~T}$ & $\mathrm{C}$ & 0.3809 \\
\hline & rs1176744 & $113,932,306$ & $\mathrm{G}$ & $\mathrm{T}$ & 0.1646 \\
\hline & rs2276305 & $113,932,382$ & A & $\mathrm{G}$ & 0.2479 \\
\hline & rs3782025 & $113,936,885$ & $\mathrm{C}$ & $\mathrm{T}$ & 0.3846 \\
\hline & rs 1672717 & $113,942,011$ & $\mathrm{C}$ & $\mathrm{T}$ & 0.4038 \\
\hline & rs 12795805 & $113,946,958$ & $\mathrm{C}$ & $\mathrm{T}$ & 0.1639 \\
\hline
\end{tabular}

\section{Statistical analysis}

The variances in the genotypes, haplotypes, and alleles at each locus in the study and control groups were analyzed using the Pearson chi-square test or Fisher exact test to discover SNPs associated with the disease. Hardy-Weinberg equilibrium exact test and MAF were performed using Plink 1.07 (Purcell et al., 2007). Quantitative analyses, such as $t$-tests and chi-square tests, were performed using the SPSS software, version 20.0 (SPSS Inc., Chicago, IL, USA). Disease association analysis was performed using Haploview version 4.2 (Barrett et al., 2005). The "TCC" genotype of rs3831455 was replaced by "T" and "DEL" was replaced by "G" per the requirements of Haploview 4.2 for genotyping. "D" was used to measure the LDs of the loci. The global permutation test was based on the null hypothesis that all odds ratios (ORs) of haplotypes were equal and that the $\mathrm{P}$ value was corrected after 10,000 permutations. $\mathrm{P}$ values $<0.05$ were considered to be statistically significant and were used to establish associations.

\section{RESULTS}

\section{Association analyses of tag SNPs}

All of the subjects in the patient and control groups were genotyped at a call rate of $>97 \%$ for every tag SNP that did not violate Hardy-Weinberg equilibrium. A complete list of the individual variants is presented in Table 2. The "A" allele in HTR3A, rs1176719 $(\mathrm{P}=0.030)$ and the " $\mathrm{C}$ " allele in $\mathrm{rs} 1176713(\mathrm{P}=0.048)$ were significantly associated with BPD. The pathogenic ORs for these alleles were 1.605 [95\% confidence interval $(\mathrm{CI})=$ $1.044-2.468]$ and $1.472(95 \% \mathrm{CI}=1.054-2.473)$, respectively. The allelic frequencies of

Genetics and Molecular Research 15 (3): gmr.15038671 
the other tag SNPs in the patient and control samples were not found to be significantly associated with BPD $(\mathrm{P}>0.05)$.

Table 2. Association analysis of tag SNPs.

\begin{tabular}{|c|c|c|c|c|c|c|c|}
\hline \multirow[t]{2}{*}{ Tag SNP } & \multirow[t]{2}{*}{ Minor allele } & \multicolumn{2}{|c|}{ Allele frequency } & \multirow[t]{2}{*}{$\mathrm{P}$} & \multirow[t]{2}{*}{ OR } & \multicolumn{2}{|c|}{$95 \% \mathrm{CI}$} \\
\hline & & Case & Control & & & L95 & U95 \\
\hline \multicolumn{8}{|l|}{ HTR3A } \\
\hline rs 10789980 & G & 0.387 & 0.358 & 0.516 & 1.132 & 0.778 & 1.645 \\
\hline rs 1062613 & $\mathrm{~T}$ & 0.121 & 0.101 & 0.487 & 1.227 & 0.688 & 2.190 \\
\hline rs 11604247 & $\mathrm{~T}$ & 0.133 & 0.097 & 0.230 & 1.422 & 0.798 & 2.532 \\
\hline rs1176722 & $\mathrm{A}$ & 0.129 & 0.096 & 0.266 & 1.388 & 0.777 & 2.479 \\
\hline rs2276302 & $\mathrm{G}$ & 0.133 & 0.101 & 0.284 & 1.364 & 0.772 & 2.412 \\
\hline$r s 1176719$ & $\mathrm{~A}$ & 0.285 & 0.199 & 0.030 & 1.605 & 1.044 & 2.468 \\
\hline rs 10160548 & G & 0.359 & 0.307 & 0.232 & 1.264 & 0.861 & 1.857 \\
\hline$r s 1176713$ & $\mathrm{C}$ & 0.416 & 0.324 & 0.048 & 1.472 & 1.054 & 2.473 \\
\hline rs 1182457 & $\mathrm{~T}$ & 0.125 & 0.101 & 0.411 & 1.273 & 0.716 & 2.263 \\
\hline rs 897685 & $\mathrm{G}$ & 0.094 & 0.106 & 0.645 & 0.868 & 0.475 & 1.586 \\
\hline \multicolumn{8}{|l|}{ HTR3B } \\
\hline rs 10789970 & $\mathrm{C}$ & 0.394 & 0.431 & 0.419 & 0.860 & 0.595 & 1.241 \\
\hline rs3758987 & $\mathrm{G}$ & 0.184 & 0.161 & 0.509 & 1.176 & 0.727 & 1.901 \\
\hline rs3831455 & DEL.TCC & 0.15 & 0.170 & 0.634 & 0.887 & 0.543 & 1.450 \\
\hline rs4938056 & $\mathrm{C}$ & 0.410 & 0.445 & 0.445 & 0.867 & 0.602 & 1.250 \\
\hline rs 12421126 & $\mathrm{C}$ & 0.244 & 0.211 & 0.429 & 1.202 & 0.762 & 1.896 \\
\hline rs 1176746 & $\mathrm{~T}$ & 0.364 & 0.404 & 0.378 & 0.845 & 0.582 & 1.228 \\
\hline rs1176744 & G & 0.181 & 0.142 & 0.254 & 1.334 & 0.812 & 2.192 \\
\hline rs2276305 & $\mathrm{A}$ & 0.242 & 0.243 & 0.981 & 0.995 & 0.653 & 1.516 \\
\hline rs 3782025 & $\mathrm{C}$ & 0.369 & 0.406 & 0.407 & 0.854 & 0.587 & 1.241 \\
\hline rs 1672717 & $\mathrm{C}$ & 0.391 & 0.427 & 0.427 & 0.862 & 0.597 & 1.244 \\
\hline rs 12795805 & $\mathrm{C}$ & 0.184 & 0.138 & 0.176 & 1.410 & 0.856 & 2.320 \\
\hline
\end{tabular}

\section{Haplotype-based association analysis}

LD statistics for HTR3A and HTR3B were determined using Haploview 4.2 (Gabriel et al., 2002). Haplotype blocks were used to measure LD. Samples from patients with BPD exhibited substantial LD amongst themselves (Figure 1). Sixteen of 21 polymorphism sites were in the highest disequilibrium state and exerted strong effects on susceptibility to BPD. We detected two LD blocks each within HTR3A and HTR3B. As shown in Figure 1, the number and the color of the square indicates $\mathrm{D}^{\prime}(100 \mathrm{X})$ and the gray square denotes $\mathrm{D}^{\prime}=1$. The gradient colors demonstrate the strengths of the LDs of the tag SNPs.

In HTR3B, LD block 1 was formed by two tag SNPs (rs10789970 and rs3758987). The frequencies of none of the three haplotypes (TA, TC, and TG) were significantly different $(\mathrm{P}>0.05)$ between the patient group and the healthy control group. Six tag SNPs (rs12421126, rs1176746, rs1176744, rs22763 05, rs3782025, and rs1672717) formed LD block 2 and encompassed five haplotypes. None of these haplotypes was significantly associated with BPD ( $\mathrm{P}>0.05)$. rs 3831455 , rs4938056, and rs 12795805 did not form a haplotype.

In HTR3A, the LD block 3 haplotype was formed by five tag SNPs (rs1062613:C, rs11604247:C, rs1176722:G, rs2276302:A, and rs1176719:G), which had nominally significantly different frequencies in the two groups $(\mathrm{P}$ value $=0.035)$. The other four haplotypes were not significantly associated with BPD $(\mathrm{P}>0.05)$. Three tag SNPs (rs 10160548, rs1176713, and rs1182457) formed LD block 4. None of the four haplotypes detected in block 4 were significantly associated with BPD $(\mathrm{P}>0.05)$. rs10789970 and rs897685 did not form any haplotypes within HTR3A (Figure 1 and Table 3).

Genetics and Molecular Research 15 (3): gmr.15038671 


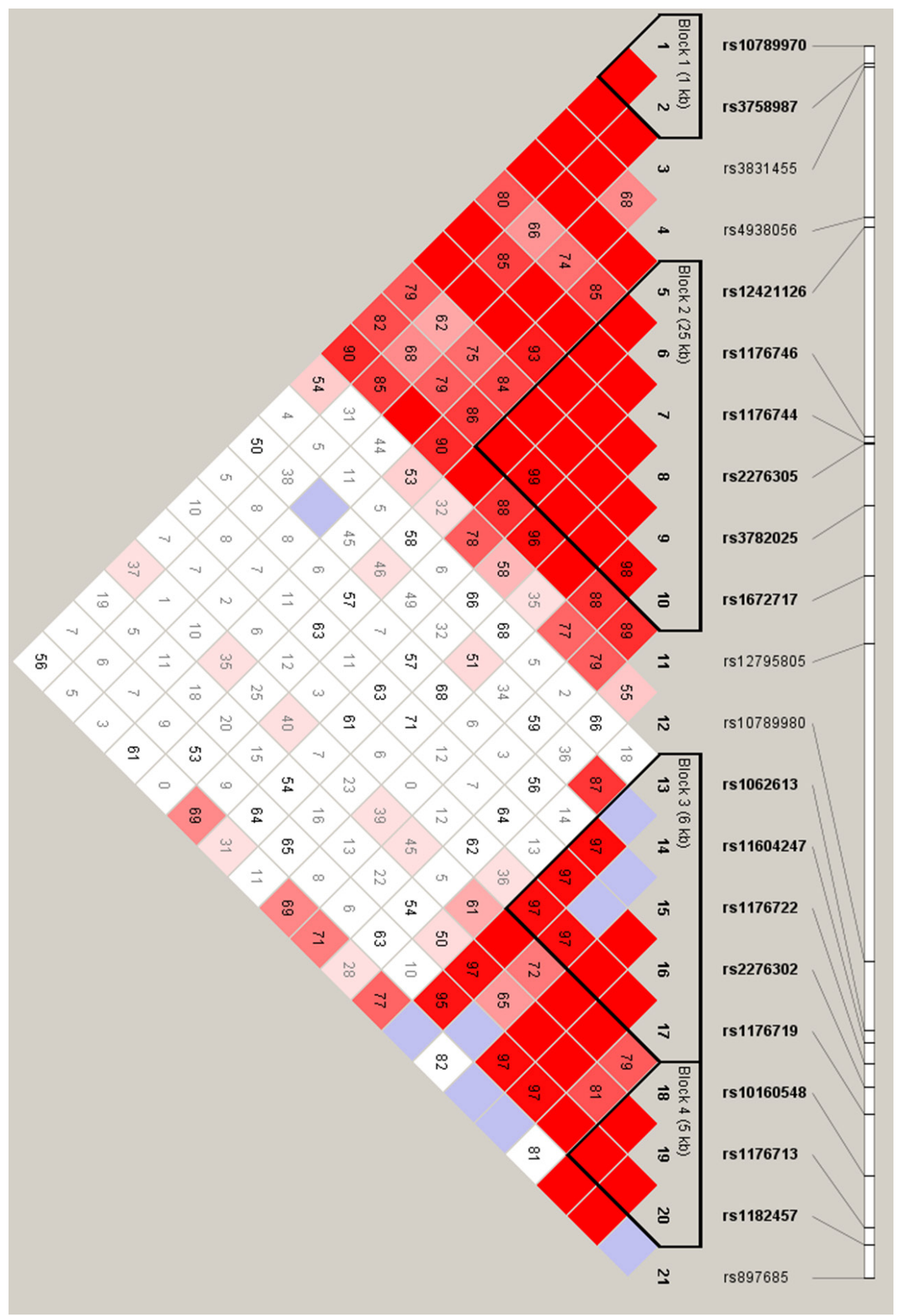

Figure 1. Linkage disequilibrium plot of HTR3A and HTR3B.

Genetics and Molecular Research 15 (3): gmr.15038671 
Table 3. Associations of haplotypes with BPD.

\begin{tabular}{|c|c|c|c|c|c|}
\hline \multirow[t]{2}{*}{$\overline{\text { Block }}$} & \multirow[t]{2}{*}{ Haplotype } & \multicolumn{2}{|c|}{ Allele frequency } & \multirow[t]{2}{*}{ Chi square } & \multirow[t]{2}{*}{$\mathrm{P}$ value } \\
\hline & & Case & Control & & \\
\hline \multirow[t]{3}{*}{$\overline{\text { Block } 1}$} & TA & 0.422 & 0.407 & 0.120 & 0.729 \\
\hline & $\mathrm{CA}$ & 0.391 & 0.430 & 0.711 & 0.399 \\
\hline & TG & 0.186 & 0.164 & 0.412 & 0.521 \\
\hline \multirow[t]{5}{*}{ Block 2} & TTTGCC & 0.360 & 0.404 & 0.937 & 0.333 \\
\hline & CCTATT & 0.240 & 0.228 & 0.094 & 0.759 \\
\hline & TCTGTT & 0.178 & 0.188 & 0.075 & 0.784 \\
\hline & TCGGTT & 0.182 & 0.142 & 1.378 & 0.240 \\
\hline & TCTGTC & 0.027 & 0.018 & 0.398 & 0.528 \\
\hline \multirow[t]{4}{*}{ Block 3} & CCGAG & 0.709 & 0.793 & 4.436 & 0.035 \\
\hline & CTGAA & 0.124 & 0.092 & 1.273 & 0.259 \\
\hline & TCAGA & 0.120 & 0.096 & 0.689 & 0.406 \\
\hline & CCGAA & 0.027 & 0.009 & 2.020 & 0.155 \\
\hline \multirow[t]{4}{*}{ Block 4} & TTC & 0.640 & 0.695 & 1.667 & 0.197 \\
\hline & GCC & 0.140 & 0.095 & 2.197 & 0.138 \\
\hline & GCT & 0.128 & 0.100 & 0.908 & 0.341 \\
\hline & GTC & 0.093 & 0.109 & 0.339 & 0.560 \\
\hline
\end{tabular}

\section{DISCUSSION}

We examined the roles of HTR3A and HTR3B in susceptibility to BPD in the Han Chinese population. Our findings support the 5-hydroxytryptamine hypothesis in the pathogenesis of BPD. Our study demonstrated that tag SNPs in HTR3A (rs1176719 and rs1176713) were significantly associated with BPD at the allelic, genotypic, and haplotype levels $(\mathrm{P}<0.05)$. The haplotype CCGAG in LD block 3 was especially associated with BPD. In addition, the sixteen polymorphisms with the highest disequilibria were associated with maximum susceptibility to BPD, indicating that HTR3A and HTR3B may play significant roles in susceptibility to BPD. rs1176713 is a synonymous SNP located on exon 8 of HTR3A and can alter its expression level. rs1176719, located in intron 8 of HTR3A may be related to the regulation of gene expression.

Interestingly, a European study and Niesler et al. (2001)'s findings confirm that the c. 178C $>$ T (p.Pro16Ser) variant in HTR3A may represent a functional variability and affect BPD susceptibility. However, we were unable to replicate this finding in our study. sr1176744 and rs3831455 in HTR3B have been shown to associate with BPD in European populations but not in Han Chinese populations.

The present study had several limitations. The small sample size of the Han Chinese from North China accounts for a diverse genetic background based on regional and ethnic factors that may affect the onset of BPD. Many genes associated with BPD risk were detected using a candidate gene approach. Examples of these genes include those coding for monoamine oxidase (MAOA), dopamine transporter (DAT), serotonin transporter (5-HTT), 5-HT2A receptors, catechol-O-methyltransferase, brain-derived neurotrophic factor, Neuregulin 1, and disrupted-in-schizophrenia 1 (Neves et al., 2008; Perlis et al., 2008; Serretti and Mandelli, 2008; Barnett and Smoller, 2009; Ferreira et al., 2009). This necessitates a multiple gene blasting approach for more in-depth research into BPD. Furthermore, the use of GWAS as a key approach has been successful in candidate gene studies. However, a critical factor is whether GWAS can be used in different populations to better understand the associations between genotypes and BPD. Thus, additional studies and a much larger sample size incorporating

Genetics and Molecular Research 15 (3): gmr.15038671 
patients from other ethnic populations are required for the validation of our results. Hitherto, gene association analyses of BPD have not been successfully replicated. This situation is also common in other studies involving complex diseases. Meanwhile, large meta-analyses can be used to evaluate relevance and effectiveness. The current study primarily focuses on HTR3A and HTR3B at the DNA level and serves as a starting point for launching further genetic investigations centered on RNA and protein expressions of the two receptors associated with BPD. This is the first study to investigate the associations of HTR3A and HTR3B with BPD in a Han Chinese population. A strong link between HTR3A and BPD susceptibility is now established.

\section{Conflicts of interest}

The authors declare no conflict of interest.

\section{ACKNOWLEDGMENTS}

We thank our research team, collaborators, and volunteers for their contributions and Huada Gene Research Center for their technical assistance.

\section{REFERENCES}

Altinay MI, Hulvershorn LA, Karne H, Beall EB, et al. (2016). Differential Resting-State Functional Connectivity of Striatal Subregions in Bipolar Depression and Hypomania. Brain Connect. 6: 255-265. http://dx.doi.org/10.1089/ brain.2015.0396

Barker JM, Zhang Y, Wang F, Taylor JR, et al. (2013). Ethanol-induced Htr3a promoter methylation changes in mouse blood and brain. Alcohol. Clin. Exp. Res. 37 (Suppl 1): E101-E107.http://dx.doi.org/10.1111/j.1530-0277.2012.01906.x

Barnes NM and Sharp T (1999). A review of central 5-HT receptors and their function. Neuropharmacology 38: 10831152. http://dx.doi.org/10.1016/S0028-3908(99)00010-6

Barnett JH and Smoller JW (2009). The genetics of bipolar disorder. Neuroscience 164: 331-343. http://dx.doi. org/10.1016/j.neuroscience.2009.03.080

Barrett JC, Fry B, Maller J and Daly MJ (2005). Haploview: analysis and visualization of LD and haplotype maps. Bioinformatics 21: 263-265.http://dx.doi.org/10.1093/bioinformatics/bth457

Bauer M and Pfennig A (2005). Epidemiology of bipolar disorders. Epilepsia 46 (Suppl 4): 8-13.http://dx.doi.org/10.1111/ j.1528-1167.2005.463003.x

Cederholm JM, Schofield PR and Lewis TM (2009). Gating mechanisms in Cys-loop receptors. Eur. Biophys. J. 39: 37-49. http://dx.doi.org/10.1007/s00249-009-0452-y

Ferreira AdeA, Neves FS, da Rocha FF, Silva GS, et al. (2009). The role of 5-HTTLPR polymorphism in antidepressantassociated mania in bipolar disorder. J. Affect. Disord. 112: 267-272.http://dx.doi.org/10.1016/j.jad.2008.04.012

Fornaro M, Orsolini L, Marini S, De Berardis D, et al. (2016). The prevalence and predictors of bipolar and borderline personality disorders comorbidity: Systematic review and meta-analysis. J. Affect. Disord. 195: 105-118. http:// dx.doi.org/10.1016/j.jad.2016.01.040

Gabriel SB, Schaffner SF, Nguyen H, Moore JM, et al. (2002). The structure of haplotype blocks in the human genome. Science 296: 2225-2229. http://dx.doi.org/10.1126/science.1069424

Hammer C, Cichon S, Mühleisen TW, Haenisch B, et al. (2012). Replication of functional serotonin receptor type 3A and B variants in bipolar affective disorder: a European multicenter study. Transl. Psychiatry 2: e103. http://dx.doi. org/10.1038/tp.2012.30

Holbrook JD, Gill CH, Zebda N, Spencer JP, et al. (2009). Characterisation of 5-HT3C, 5-HT3D and 5-HT3E receptor subunits: evolution, distribution and function. J. Neurochem. 108: 384-396. http://dx.doi.org/10.1111/j.14714159.2008.05775.x

Johnson BA, Seneviratne C, Wang XQ, Ait-Daoud N, et al. (2013). Determination of genotype combinations that can predict the outcome of the treatment of alcohol dependence using the 5-HT(3) antagonist ondansetron. Am. J. Psychiatry 170: 1020-1031.http://dx.doi.org/10.1176/appi.ajp.2013.12091163

Genetics and Molecular Research 15 (3): gmr.15038671 
Karnovsky AM, Gotow LF, McKinley DD, Piechan JL, et al. (2003). A cluster of novel serotonin receptor 3-like genes on human chromosome 3. Gene 319: 137-148. http://dx.doi.org/10.1016/S0378-1119(03)00803-5

Maricq AV, Peterson AS, Brake AJ, Myers RM, et al. (1991). Primary structure and functional expression of the 5HT3 receptor, a serotonin-gated ion channel. Science 254: 432-437.http://dx.doi.org/10.1126/science. 1718042

Merikangas KR, Akiskal HS, Angst J, Greenberg PE, et al. (2007). Lifetime and 12-month prevalence of bipolar spectrum disorder in the National Comorbidity Survey replication. Arch. Gen. Psychiatry 64: 543-552. http://dx.doi. org/10.1001/archpsyc.64.5.543

Neves FS, Silveira G, Romano-Silva MA, Malloy-Diniz L, et al. (2008). Is the 5-HTTLPR polymorphism associated with bipolar disorder or with suicidal behavior of bipolar disorder patients? Am. J. Med. Genet. B. Neuropsychiatr. Genet. 147B: 114-116. http://dx.doi.org/10.1002/ajmg.b.30563

Niesler B, Flohr T, Nöthen MM, Fischer C, et al. (2001). Association between the 5' UTR variant C178T of the serotonin receptor gene HTR3A and bipolar affective disorder. Pharmacogenetics 11: 471-475. http://dx.doi. org/10.1097/00008571-200108000-00002

Niesler B, Frank B, Kapeller J and Rappold GA (2003). Cloning, physical mapping and expression analysis of the human 5-HT3 serotonin receptor-like genes HTR3C, HTR3D and HTR3E. Gene 310: 101-111. http://dx.doi.org/10.1016/ $\underline{\text { S0378-1119(03)00503-1 }}$

Perlis RH, Purcell S, Fagerness J, Kirby A, et al. (2008). Family-based association study of lithium-related and other candidate genes in bipolar disorder. Arch. Gen. Psychiatry 65: 53-61.http://dx.doi.org/10.1001/archgenpsychiatry.2007.15

Purcell S, Neale B, Todd-Brown K, Thomas L, et al. (2007). PLINK: a tool set for whole-genome association and populationbased genome-wide association studies analyses. Am. J. Hum. Genet. 81: 559-575.http://dx.doi.org/10.1086/519795

Seneviratne C, Franklin J, Beckett K, Ma JZ, et al. (2013). Association, interaction, and replication analysis of genes encoding serotonin transporter and 5-HT3 receptor subunits A and B in alcohol dependence. Hum. Genet. 132: 11651176. http://dx.doi.org/10.1007/s00439-013-1319-y

Serretti A and Mandelli L (2008). The genetics of bipolar disorder: genome 'hot regions,' genes, new potential candidates and future directions. Mol. Psychiatry 13: 742-771. http://dx.doi.org/10.1038/mp.2008.29

Tang WK, Tang N, Liao CD, Liang HJ, et al. (2013). Serotonin receptor 2C gene polymorphism associated with poststroke depression in Chinese patients. Genet. Mol. Res. 12: 1546-1553. http://dx.doi.org/10.4238/2013.May.13.8

Tee SF, Chow TJ, Tang PY and Loh HC (2010). Linkage of schizophrenia with TPH2 and 5-HTR2A gene polymorphisms in the Malay population. Genet. Mol. Res. 9: 1274-1278. http://dx.doi.org/10.4238/vol9-3gmr789

Tencomnao T, Thongrakard V, Phuchana W, Sritharathikhun T, et al. (2010). No relationship found between -1438A/G polymorphism of the serotonin 2A receptor gene (rs6311) and major depression susceptibility in a northeastern Thai population. Genet. Mol. Res. 9: 1171-1176. http://dx.doi.org/10.4238/vol9-2gmr823

Weber H, Kittel-Schneider S, Gessner A, Domschke K, et al. (2011). Cross-disorder analysis of bipolar risk genes: further evidence of DGKH as a risk gene for bipolar disorder, but also unipolar depression and adult ADHD. Neuropsychopharmacology 36: 2076-2085. http://dx.doi.org/10.1038/npp.2011.98

Yamada K, Hattori E, Iwayama Y, Ohnishi T, et al. (2006). Distinguishable haplotype blocks in the HTR3A and HTR3B region in the Japanese reveal evidence of association of HTR3B with female major depression. Biol. Psychiatry 60 : 192-201.http://dx.doi.org/10.1016/j.biopsych.2005.11.008

Genetics and Molecular Research 15 (3): gmr.15038671 